\title{
Evaluation of different dietary additives based on growth performance, innate immunity and disease resistance in juvenile Amur catfish, Silurus asotus
}

\author{
Yaa Tiwaah Amoah • Mohammad Moniruzzaman - Seunghan Lee • \\ Jinho Bae · Seonghun Won • Minji Seong • Sungchul C. Bai $\mathbb{D}^{\circ}$
}

Received: 19 April 2017/Accepted: 20 October 2017/Published online: 28 October 2017

(C) The Author(s) 2017. This article is an open access publication

\begin{abstract}
Three different dietary additives were evaluated based on growth performance, innate immune responses and disease resistance in juvenile Amur catfish Silurus asotus. Four diets were prepared by supplementing $0.4 \%$ Song-gang ${ }^{\circledR}$ stone (SG), $0.05 \%$ Yucca meal (YM), $0.05 \% \beta$-glucan (BG) in combination with $0.04 \% \mathrm{SG}$ and $0.05 \% \mathrm{BG}(\mathrm{SG}+\mathrm{BG})$ to a basal commercial diet (control; CONT). Triplicate groups of fish averaging $4.95 \pm 0.05 \mathrm{~g}$ were fed one of the test diets between 3 and $5 \%$ body weight for 8 weeks. At the end of the feeding trial, weight gain, specific growth rate, feed efficiency and protein efficiency ratio of fish fed $\mathrm{SG}$ and $\mathrm{SG}+\mathrm{BG}$ were significantly higher than those of fish fed the BG and CONT diets $(P<0.05)$. Lysozyme activity in fish fed the SG, YM, and SG + BG diets was significantly higher than those of fish fed the CONT diet. Super oxide dismutase (SOD) activity was significantly higher among fish fed the SG, YM, $\mathrm{BG}$ and $\mathrm{SG}+\mathrm{BG}$ diets than fish fed the CONT diet. After 14 days challenge test with Edwardsiella tarda, cumulative survival rates of fish fed the $\mathrm{SG}$ and $\mathrm{SG}+\mathrm{BG}$ diets were significantly higher than those of fish fed the BG and CONT diets. Results revealed that dietary SG or SG + BG diets had positive responses over other additives in juvenile Amur catfish. However, Song-gang ${ }^{\circledR}$ stone is proposed to be a cheaper dietary additive contributing 0.04 cents $/ \mathrm{kg}$ of feed based on economic point of view.
\end{abstract}

Keywords Amur catfish · Song-gang ${ }^{\circledR}$ stone · Yucca meal · $\beta$-Glucan · Growth · Immune responses

\section{Introduction}

Aquaculture has continuously intensified due to decreased wild capture and increased demand for the food fish. Production of the food fish from aquaculture reached 70.2 million tons in 2013 (FAO 2015). The intensification of aquaculture exposes cultured animals to stressful conditions, pathogens, and leads to deterioration of the environment, which leads to growth suppression, disease outbreaks, products of low market value and eventually significant economic losses (Sakai 1999; Rufchaie and Hoseinifar 2014). To reduce the economic losses caused by poor growth and disease outbreaks in aquaculture, the identification, development and application of natural, practical and cost-effective dietary additives can modulate immune responses as well as can promote growth of farmed fish (Halver and Hardy 2002; Harikrishnan et al. 2011; NRC 2011).

Y. T. Amoah $\cdot$ M. Moniruzzaman $\cdot$ S. Lee $\cdot$ J. Bae $\cdot$ S. Won $\cdot$ M. Seong $\cdot$ S. C. Bai $(\square)$

Department of Marine Bio-materials and Aquaculture/Feeds and Foods Nutrition Research Center, Pukyong National

University, Busan 608-737, Republic of Korea

e-mail: scbai@pknu.ac.kr 
These approaches have recently gained attention among fish nutritionists, aquaculture researchers and farmers globally. Feed additives generally used in aquaculture are growth promoters, immune enhancers, antimicrobial agents, antioxidants, binding agents, enzymes, organic acids, feeding/palatability enhancers, probiotics and prebiotics and hormones (NRC 2011). They are added in the aqua feeds to increase the physical or chemical properties of the feed in terms of enhancing fish performance or the quality of resulting product. Nonetheless, during the selection of feed additives their contribution to feed costs should also be considered, since feed costs depending on the source and quality of the protein account for about $40-50 \%$ of the total production costs in aquaculture (Craig and Helfrich 2009).

Immune stimulants are naturally occurring compounds that modulate the immune system by increasing the host's resistance against diseases caused by pathogens (Bricknell and Dalmo 2005). They stimulate nonspecific immune responses when given alone or the specific immune responses given with an antigen. Dosages of immune stimulants that have been given to aquatic organisms play an important role in the stimulation of immune response (Meena et al. 2013). Immune stimulants include the extracts from naturally occurring minerals, plants, microbes and animal infractions (NRC 2011). Song-gang ${ }^{\circledR}$ stone (SG) is a naturally sourced and purified mineral material from the Republic of Korea comprising predominantly of iron oxide $\left(\mathrm{Fe}_{2} \mathrm{O}_{3}\right)$, silicon dioxide $\left(\mathrm{SiO}_{2}\right)$, aluminum oxide $\left(\mathrm{Al}_{2} \mathrm{O}_{3}\right)$, potassium oxide $\left(\mathrm{K}_{2} \mathrm{O}\right)$, sodium oxide $\left(\mathrm{Na}_{2} \mathrm{O}\right)$, and other trace compounds (Lee et al. 2015a; Won et al. 2017). It is considered as one of the important naturally sourced mineral materials that enhances the health status of fish (Choi et al. 2004; Lee et al. 2015b; Won et al. 2017). Fish farmers in the Republic of Korea use Song-gang stone ${ }^{\circledR}$ (SG) at $0.5 \%$ as dietary inclusion which gives a positive response in olive flounder aquaculture (Choi et al. 2004). Lee et al. (2015a) suggested that $0.4 \%$ (dry matter basis) is the optimum dietary inclusion level for yellow loess (YL) in the diet of rainbow trout. Likewise, Won et al. (2017) found that $0.4 \%$ of SG or YL supplemented diet could replace oxytetracycline (OTC) in juvenile and subadult rainbow trout. The Yucca schidigera (Agavaceae) has been recognized as an immune stimulant with anti-inflammatory effects (Cheeke et al. 2006). It contains active phytochemicals and a rich source of steroidal saponins (Piacente et al. 2005). Yucca polyphenols also act as antioxidants (Oakenfull and Sidhu 2005; Piacente et al. 2005). Yucca extracts have been found to promote growth, improve immune system, antimicrobial ability and stimulate appetite and anti-stress characteristics. Inclusion levels of yucca extract in aqua feeds include: $0.075 \%$ (Gaber 2006) and 0.1-0.58\% for Nile tilapia (Njagi et al. 2017), $0.1 \%$ for striped catfish (Güroy et al. 2014). The $\beta$-glucan (BG) is an inactivated natural microbial product that is also recognized for its immunomodulatory roles in aquatic organisms (NRC 2011). Positive effects of the $\beta$ glucan on growth, survival, and immune response of fish species against infectious pathogens has been demonstrated either alone or in combination with other immune stimulants or probiotics (Meena et al. 2013). It influences non-specific or innate immune responses such as increased lysozyme production and superoxide anion production in activated macrophages, thereby, reducing fish mortality when exposed to pathogens (NRC 2011). Low doses of $\beta$-glucan have been suggested to enhance growth and innate immunity in different cultured fish species (Ai et al. 2007; Yoo et al. 2007; Das et al. 2013; Sirimanapong et al. 2015).

The Amur catfish, Silurus asotus, belongs to the family Siluridae (sheatfishes). It is distributed in Japan, Republic of Korea, China and Taiwan. It is the second freshwater farmed fish species with a production of 4607 tons in the Republic of Korea in 2014 (FAO 2016). Several dietary additives have been identified to promote growth and immune responses in the aquaculture industry (Choi et al. 2004; Ai et al. 2007; Yoo et al. 2007; NRC 2011; Güroy et al. 2014; Lee et al. 2015b; Shahkar et al. 2015); however, each dietary additive could produce different levels of responses in individual fish species and contribute differently to feed cost. In this regard, the effects of dietary additives from mineral sources have not yet been investigated in Amur catfish. Consequently, this study was designed to evaluate the effects of dietary SG, YM, BG and a combination of SG and BG on growth performance, innate immune responses and disease resistance in juvenile Amur catfish.

\section{Methods}

Experimental design and diets

A basal commercial catfish diet (Catfish premium; Woosung Feed Co. Ltd, Republic of Korea) (Table 1) without additive inclusion was used as the control diet and four other diets were prepared by supplementing 
Table 1 Proximate composition (\% dry matter basis) of the basal diet

\begin{tabular}{lr}
\hline Proximate content & \% Composition \\
\hline Moisture & 6.7 \\
Crude protein & 47.4 \\
Crude lipid & 9.5 \\
Crude ash & 11.7 \\
Nitrogen free extract & a
\end{tabular}

Woosung Fish Feed Company, Daejeon, Republic of Korea

${ }^{\mathrm{a}}$ Nitrogen free extract $=100-($ moisture + protein + lipid + ash $)($ Castell and Tiews 1980$)$

Table 2 Experimental diets and the inclusion rates of feed additives used to feed the juvenile Amur catfish for 8 weeks

\begin{tabular}{llllll}
\hline Additives (\%) & Diets & & & \\
\cline { 2 - 6 } & CONT & SG & YM & BG & SG + BG \\
\hline Song-gang ${ }^{\circledR}$ stone & 0 & 0.4 & 0 & 0 & 0.4 \\
Yucca meal & 0 & 0 & 0.05 & 0 & 0 \\
$\beta$-glucan & 0 & 0 & 0 & 0.05 & 0.05
\end{tabular}

CONT (control)—basal diet (Woosung Fish Feed Company, Daejeon, Republic of Korea), SG 0.4\% Song-gang ${ }^{\circledR}$ stone (Davistone Co. Ltd., Busan, South Korea) + basal diet, $Y M-0.05 \%$ Yucca meal (as De-Odorase ${ }^{\circledR}$ Alltech Korea, Seoul, Rep. of Korea) + basal diet, $B G 0.05 \%$-glucan (as CitriStim ${ }^{\circledR}$, Flavour Cooperation of Korea, Seoul, Republic of Korea) + basal diet, $S G+B G$ $0.4 \%$ Song-gang ${ }^{\circledR}$ stone $+0.05 \% \beta$-glucan + basal diet

$0.4 \%$ Song-gang ${ }^{\circledR}$ stone (SG) which contains $73.4 \%$ silicon dioxide $\left(\mathrm{SiO}_{2}\right)$ and $15.5 \%$ aluminum oxide $\left(\mathrm{Al}_{2} \mathrm{O}_{3}\right), 0.05 \%$ Yucca meal (YM) which contains $30 \%$ Yucca schidigera extract and $2.39 \%$ saponin, $0.05 \% \beta-$ glucan (BG) which comes from yeast cell wall and a combination of $0.4 \% \mathrm{SG}$ and $0.05 \% \mathrm{BG}$ (SG + BG) (Table 2). The supplementations of the additives are based on our previous research findings (Yoo et al. 2007; Njagi et al. 2017; Won et al. 2017). The unit price of SG, YM and BG is US\$ $0.89 / \mathrm{kg}$, US\$ $15.21 / \mathrm{kg}$, US\$ $26.84 / \mathrm{kg}$, respectively; and the price contribution for the unit $\mathrm{kg}$ of feed of SG, YM and BG is US 0.04 cents $(\phi)$, US 0.08 cents $(\phi), 1.34$ cents $(\phi)$ and US 1.7 cents $(\phi)$, respectively. The commercial feed was grounded into powder with a laboratory grinding machine and sieved before addition of the feed additives. Required levels of the feed additives were weighed with an electronic balance $( \pm 0.01 \mathrm{~g})$ and solubilised with filtered tap water before its addition to the powdered feed and mixed in a laboratory electric feed mixer. Water was added at $50 \mathrm{~mL} / 100 \mathrm{~g}$ feed. The resultant mixture was pelleted with a laboratory pelleting machine without heating using a 2-mm diameter module (Baokyong Commercial Co., Busan, Republic of Korea) and air dried for 3 days. The dried feeds were sieved and packaged in zipper bags, labeled and stored at $-20{ }^{\circ} \mathrm{C}$ before the feeding trial.

Fish and feeding trial

The study was conducted at the Feeds and Foods Nutrition Research Centre (FFNRC), Pukyong National University, Busan, Republic of Korea. A total of 400 juveniles of Amur catfish were obtained from the Namsangju fish farm (Namsangju, Republic of Korea). Prior to the start of the feeding trial, all fish were fed the basal diet twice a day for 2 weeks to acclimate with the experimental condition. The feeding trial was conducted in an indoor semi-recirculating system with 15 aquaria $(50 \mathrm{~L})$ receiving a constant water flow of filtered freshwater at the rate of $2 \mathrm{~L} / \mathrm{min}$ from the central tank. Half of the water was exchanged daily by pumping filtered fresh water to the central tank. Supplemental aeration was provided to maintain dissolved oxygen level near saturation and water temperature was maintained at $25.0 \pm 0.1{ }^{\circ} \mathrm{C}$ using water heaters throughout the experimental period. Three hundred fish averaging $4.92 \pm 0.05 \mathrm{~g}$ [mean \pm standard deviation (SD)] were weighed and randomly distributed into the 15 indoor aquaria (20 fish/tank). Each aquarium was then randomly assigned one of three replicates of the five dietary treatments. Fish were fed one of the above mentioned diets twice daily (0900 and 1800 hours) ad libitum for 8 weeks. Experimental tanks were siphoned 
$2 \mathrm{~h}$ after feeding to remove fecal matter and uneaten feed. Mortality was checked daily; dead fish were removed immediately and weighed, and the amount of feeds for the tanks adjusted to the proper percentage of the remaining fish weight in the tanks. Dead fish were not replaced during the experiment. Total fish weight in each aquarium was determined at the end of the fourth week as the mid-term sampling and the amount of diet fed to the fish was adjusted accordingly. Finally, the total fish weights in the aquaria were measured at the end of the eighth week. Fish were starved $24 \mathrm{~h}$ before each measurement to avoid inclusion of ingested feed in the weight measurements as well as to minimize stress.

Sample collection and analysis

At the end of the feeding trial, all the fish in each aquarium were counted and weighed to calculate weight gain (WG), specific growth rate (SGR), feed efficiency (FE), protein efficiency ratio (PER), and survival rate (SR). Three fish per aquarium were randomly selected, weighed, and measured to calculate condition factor (CF); and then the fish were dissected to obtain liver and visceral masses for the calculation of hepatosomatic (HSI) and viscerosomatic (VSI) indices, respectively.

Prior to the collection of liver and visceral masses for the HSI and VSI calculations, respectively, the same fish were also used to analyze serological characteristics. For the blood collection, fish were first euthanized with ethylene glycol phenyl ether $(200 \mathrm{mg} / \mathrm{L})$. Blood samples were obtained from the caudal vein of the fish with $1 \mathrm{ml}$ syringes. Serum samples were obtained from the blood on clotting by centrifugation at $5000 \times g$ for $10 \mathrm{~min}$ and stored at $-70^{\circ} \mathrm{C}$ for the analysis of lysozyme and superoxide dismutase (SOD) activities. A turbidometric assay was used to analyze serum lysozyme activity (Sigma-Aldrich, St. Louis, MO, USA). The bacterium, Micrococcus lysodeikticus $(0.75 \mathrm{mg} / \mathrm{mL})$ was suspended in a sodium phosphate buffer $(0.1 \mathrm{M}, \mathrm{pH}$ 6.24), $200 \mu \mathrm{l}$ of suspension was placed in each well of 96-well plates and $20 \mu \mathrm{L}$ of test serum was added subsequently. The reduction in absorbance of the samples was recorded at $450 \mathrm{~nm}$ after incubation at room temperature $\left(25^{\circ} \mathrm{C}\right.$ ) for 0 and $60 \mathrm{~min}$ in a microplate reader (UVM 340, Biochrom, Cambridge, UK). A reduction in absorbance of $0.001 / \mathrm{min}$ was regarded as one unit of lysozyme activity. The lysozyme activity was calculated using the following equation:

$$
\text { Units } / \mathrm{ml}=\left(\Delta \mathrm{A}_{450} / \text { minutes } \times 1000\right) / \mathrm{mL} \text { enzyme in reaction mixture. }
$$

Superoxide dismutase (SOD) activity was measured by the percentage of reaction inhibition rate of the enzyme with WST-1 (Water Soluble Tetrazolium dye) substrate and xanthine oxidase using a SOD Assay Kit (Enzo ADI-900-157, Enzo Life Sciences Inc., Farmingdale, NY, USA) in accordance with the manufacturer's protocol. Each endpoint assay was monitored by absorbance at $450 \mathrm{~nm}$ (the absorbance-wavelength for the colored product of WST-1 reaction with superoxide) after $20 \mathrm{~min}$ of reaction time at $37{ }^{\circ} \mathrm{C}$. The percentage of inhibition was normalized by $\mathrm{mg}$ protein and presented as SOD activity units. Portions of serum were also used for analyses of biochemical parameters including serum total protein, glutamic oxaloacetic transaminase (GOT), glutamic pyruvic transaminase (GPT) and glucose using the commercial clinical kits with an analyzer (Fuji DRI-CHEM 3500i, Fuji Photo Film Ltd, Tokyo, Japan).

Three fish per aquarium were taken and pooled together according to the type of the diet fed and then homogenized and freeze-dried at $-80^{\circ} \mathrm{C}$ for analysis. Proximate compositions of basal diet and fish were determined according to the standard procedures of AOAC (2000) in duplicate. Samples were dried to a constant weight at $105{ }^{\circ} \mathrm{C}$ to determine the moisture content. Ash content was determined by incineration in a muffle furnace at $550^{\circ} \mathrm{C}$ for $3.5 \mathrm{~h}$, crude lipid by ether extraction using the Soxtec system 1046 (Tecator AB, Hoganas, Sweden) and crude protein by the Kjeldahl method $(N \times 6.25)$ after acid digestion.

The lyophilized pathogenic bacterium, Edwardsiella tarda (ATCC 15947, American Type Culture Collection) was obtained from the Department of Biotechnology, Pukyong National University, Busan, Republic of Korea. The E. tarda culture and identification process was followed by Park et al. (2016) with slight modifications. Briefly, thawed and fresh E. tarda was cultured in tryptic soy broth (TSB; Sigma-Aldrich) at $26{ }^{\circ} \mathrm{C}$ for $24 \mathrm{~h}$ and stored at $-80{ }^{\circ} \mathrm{C}$ for further use. Bacterial growth was measured at $\mathrm{OD}_{600}$ by spectrometer (Lambda 35; Perkin-Elmer, Waltham, MA, USA) followed by plate counting of colonies grown on tryptic soy agar (TSA; Sigma-Aldrich). The bacterial colony was identified by the API 20 E pathogenic bacteria identification kit (BioMérieux, Durham, NC, USA). Five fish were selected from each aquarium and acclimatized 
for $24 \mathrm{~h}$ after the feeding trial. Each fish was injected intraperitoneally with $0.1 \mathrm{~mL}$ of fresh bacterial suspension at a concentration of $2 \times 10^{8}$ colony-forming units $(\mathrm{CFU}) / \mathrm{mL}$ based on a preliminary virulence test $\left(50 \%\right.$ lethal dose, $\left.\mathrm{LD}_{50}\right)$ in groups of fish using the pathogenic bacterium $E$. tarda at different concentrations $\left(10^{6}-10^{10} \mathrm{CFU} / \mathrm{mL}\right.$ ) for 7 days (data not shown). The cumulative survival rate of fish was monitored and fish mortality was recorded daily up to 14 days. For the confirmation of virulence of the bacterium, E. tarda, swabs from skin, gill, liver and kidney of dead fish were checked on modified selective agar at $22{ }^{\circ} \mathrm{C}$ for $72 \mathrm{~h}$ in incubation and we confirmed that the mortality was due to the E. tarda by $16 \mathrm{~S}$ rRNA gene sequencing.

\section{Statistical analysis}

All data were subjected to one-way analysis of variance (ANOVA) using SAS Program Version 9.1(SAS Institute, Cary, NC, USA) to test the effects of the different dietary treatments. When a significant effect was observed, Tukey's post hoc test was used to compare the means. Treatment effects were considered significant at confidence level of $P<0.05$. Survival analysis in challenge test was done based on Kaplan and Meier (1958) to determine the differences among survival curves (K-M curves). All data are presented as mean $\pm \mathrm{SD}$.

\section{Results and discussion}

The present study demonstrated that the dietary additives produced different response levels in terms of growth, feed utilization, immune responses and disease resistance in juvenile Amur catfish. The results revealed a more positive response of juvenile Amur catfish to Song-gang ${ }^{\circledR}$ stone (SG) as well as combination of SG and $\beta$-glucan (SG + BG) compared with Yucca meal (YM), $\beta$-glucan (BG) and control (CONT) diets. The additives, $\beta$-glucan and Yucca meal have already shown their immunostimulating effects on fish (Yoo et al. 2007; Njagi et al. 2017). In this study, the results demonstrated the potential effect of a mineral-based additive such as Song-gang ${ }^{\circledR}$ stone in the juvenile Amur catfish.

Growth

Growth performance of juvenile Amur catfish fed the experimental diets for 8 weeks is summarized in Table 3. At the end of the feeding trial, weight gain (WG) and specific growth rate (SGR) of fish fed Songgang $^{\circledR}$ stone $(\mathrm{SG})$ and a combination of $\mathrm{SG}$ and $\beta$-glucan $(\mathrm{SG}+\mathrm{BG})$ containing diets were significantly higher than those of fish fed the BG and control (CONT) diets $(P<0.05)$. However, there were no significant differences among those of fish fed the SG, SG + BG and YM diets, between those of fish fed the YM and BG diets as well as between those of fish fed the BG and CONT diets. Likewise, feed efficiency (FE) and protein efficiency ratio (PER) of fish fed the $\mathrm{SG}$ and $\mathrm{SG}+\mathrm{BG}$ diets were significantly higher than those of fish fed the $\mathrm{BG}$ and CONT diets $(P<0.05)$. However, there were no significant differences in FE and PER among fish fed the SG, SG + BG and YM diets $(P>0.05)$. Moreover, fish fed the YM, BG and CONT diets did not show significant differences in terms of FE and PER. The observations with the SG diet is comparable to the findings by Lee et al. (2015b) and Won et al. (2017) with Song-gang ${ }^{\circledR}$ stone and yellow loess, respectively, in rainbow trout Oncorhynchus mykiss as well as Shahkar et al. (2015) with Macsumsuk ${ }^{\circledR}$ in Nile tilapia Oreochromis niloticus. Growth and feed efficiency improved in olive flounder Paralichthys olivaceus fed a combination of $\beta$-glucan and BAISM-contained diets (Yoo et al. 2007). Measurement and analysis of condition factor (CF), hepatosomatic index (HSI) and viscerosomatic index (VSI) are important in assessing food value in an animal, its health status and general well-being as well as the degree of pollutants in the environment where the animal lives (Ighwela et al. 2014). There were no significant differences in HSI, VSI and $\mathrm{CF}$ among fish fed the experimental diets which was an indication of good nutritional and health status of fish during the feeding trial. In this study, the highest survival rates (100\%) recorded among the groups of experimental fish during the study could be attributed to the high acceptability of the experimental diets by the catfish. 
Table 3 Growth performance of juvenile Amur catfish fed the experimental diets for 8 weeks

\begin{tabular}{|c|c|c|c|c|c|}
\hline \multirow[t]{2}{*}{ Parameters } & \multicolumn{5}{|l|}{ Diets $^{\mathrm{A}}$} \\
\hline & CONT & SG & YM & BG & $\mathrm{SG}+\mathrm{BG}$ \\
\hline $\mathrm{WG}^{\mathrm{B}}$ & $475 \pm 6.8^{\mathrm{a}}$ & $493 \pm 5.2^{\mathrm{c}}$ & $486 \pm 6.3^{b c}$ & $481 \pm 8.3^{\mathrm{ab}}$ & $492 \pm 2.6^{\mathrm{c}}$ \\
\hline $\mathrm{SGR}^{\mathrm{C}}$ & $3.89 \pm 0.03^{\mathrm{a}}$ & $3.96 \pm 0.02^{\mathrm{c}}$ & $3.93 \pm 0.02^{\mathrm{bc}}$ & $3.91 \pm 0.03^{\mathrm{ab}}$ & $3.95 \pm 0.01^{\mathrm{c}}$ \\
\hline $\mathrm{FE}^{\mathrm{D}}$ & $127 \pm 2.3^{\mathrm{a}}$ & $138 \pm 0.6^{\mathrm{b}}$ & $133 \pm 0.7^{\mathrm{ab}}$ & $132 \pm 4.9^{\mathrm{a}}$ & $138 \pm 4.8^{\mathrm{b}}$ \\
\hline $\mathrm{PER}^{\mathrm{E}}$ & $2.69 \pm 0.05^{\mathrm{a}}$ & $2.91 \pm 0.01^{\mathrm{b}}$ & $2.80 \pm 0.02^{\mathrm{ab}}$ & $2.78 \pm 0.1^{\mathrm{a}}$ & $2.92 \pm 0.1^{\mathrm{b}}$ \\
\hline $\mathrm{HSI}^{\mathrm{F}}$ & $1.11 \pm 0.1$ & $1.18 \pm 0.1$ & $1.18 \pm 0.1$ & $1.17 \pm 0.1$ & $1.23 \pm 0.2$ \\
\hline $\mathrm{VSI}^{\mathrm{G}}$ & $3.28 \pm 0.6$ & $3.21 \pm 0.4$ & $3.05 \pm 0.4$ & $3.15 \pm 0.6$ & $3.07 \pm 0.5$ \\
\hline $\mathrm{CF}^{\mathrm{H}}$ & $0.61 \pm 0.04$ & $0.58 \pm 0.1$ & $0.55 \pm 0.05$ & $0.59 \pm 0.03$ & $0.61 \pm 0.1$ \\
\hline Survival $^{\mathrm{I}}$ & $100 \pm 0.0$ & $100 \pm 0.0$ & $100 \pm 0.0$ & $100 \pm 0.0$ & $100 \pm 0.0$ \\
\hline
\end{tabular}

Values are mean \pm SD for the triplicate groups of fish where values in each row with different superscripts are significantly different $(P<0.05)$

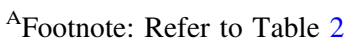

${ }^{\mathrm{B}}$ Weight gain $(\mathrm{WG})=($ final weight initial weight $) \times 100 /$ initial weight

${ }^{\mathrm{C}}$ Specific growth rate $(\mathrm{SGR} ; \%)=($ ln final weight $-\ln$ initial weight $) \times 100 /$ days

${ }^{\mathrm{D}}$ Feed efficiency $(\mathrm{FE} ; \%)=$ wet WG $(\mathrm{g}) \times 100 /$ dry feed intake $(\mathrm{g})$

${ }^{\mathrm{E}}$ Protein efficiency ratio $(\mathrm{PER})=$ wet weight gain/protein intake

${ }^{\mathrm{F}}$ Hepatosomatic index $(\mathrm{HSI} ; \%)=($ liver weight/body weight $) \times 100$

${ }^{\mathrm{G}}$ Viscerosomatic index (VSI; \%) $=($ visceral weight/body weight $) \times 100$

${ }^{\mathrm{H}}$ Condition factor $(\mathrm{CF})=\left[\right.$ fish weight $(\mathrm{g}) /$ fish length $\left.(\mathrm{cm})^{3}\right] \times 100$

${ }^{\mathrm{I}}$ Survival $(\%)=($ final number of fish/initial number of fish $) \times 100$

Whole body proximate analysis

Whole body proximate compositions of juvenile Amur catfish fed the experimental diets are summarized in Table 4. There were no significant differences in the whole body moisture and ash content among fish fed the experimental diets at the end of the feeding trial. Crude protein content in fish fed the YM diet was significantly higher than those of fish fed the SG, BG, SG + BG and CONT diets $(P<0.05)$. However, there were no significant differences in the whole body crude protein contents among fish fed the SG, BG, SG + BG and CONT diets. In contrast, crude lipid in fish fed the YM diet was significantly lower than those of fish fed the SG, BG, SG + BG and CONT diets $(P<0.05)$. Fish fed the SG, BG, SG + BG and CONT diets showed no significant differences in case of the whole body crude lipid content. Gaber (2006) reported the higher body protein content in Nile tilapia fed the Yucca-supplemented diet compared with the control diet and significantly lower body lipid content than that of the control diet. Similarly, Yilmaz et al. (2012) also reported lower crude lipid content in sea bass Dicentrarchus labrax fed the herbal extracts compared with the control diet. It can be speculated that plant extracts could reduce the crude lipid content in cultured fish.

Table 4 Whole body proximate composition of Amur juvenile catfish fed the experimental diets for 8 weeks (\% dry matter basis)

\begin{tabular}{llllll}
\hline & \multicolumn{1}{l}{ Diets $^{\mathrm{A}}$} & & & \\
\cline { 2 - 6 } & CONT & SG & YM & BG & SG + BG \\
\hline Moisture & $77.43 \pm 0.8$ & $77.63 \pm 0.2$ & $77.32 \pm 0.2$ & $77.68 \pm 0.9$ & $78.81 \pm 0.2$ \\
Crude protein & $67.01 \pm 0.4^{\mathrm{a}}$ & $66.99 \pm 0.6^{\mathrm{a}}$ & $69.36 \pm 0.2^{\mathrm{b}}$ & $66.93 \pm 0.01^{\mathrm{a}}$ & $67.20 \pm 0.1^{\mathrm{a}}$ \\
Crude lipid & $19.56 \pm 0.5^{\mathrm{a}}$ & $19.32 \pm 0.5^{\mathrm{a}}$ & $17.76 \pm 0.8^{\mathrm{b}}$ & $19.51 \pm 0.2^{\mathrm{a}}$ & $19.50 \pm 0.4^{\mathrm{a}}$ \\
Ash & $11.47 \pm 0.2$ & $11.78 \pm 0.02$ & $11.53 \pm 0.5$ & $12.46 \pm 0.1$ & $13.12 \pm 0.1$ \\
\hline
\end{tabular}

Values are mean \pm SD from the triplicate groups of fish where values in each row with different superscripts are significantly different $(P<0.05)$

${ }^{\mathrm{A}}$ Footnote: Refer to Table 2 
Serum parameters

Serum parameters of juvenile Amur catfish fed the experimental diets are summarized in Table 5. Hematological and serum parameters are good indicators of the health status of an organism and these can vary with season, temperature and nutritional status (Blaxhall 1972). Lee et al. (2016) suggested that any unhealthy condition caused by dietary treatment could affect the hematological characteristics of fish. In this study, there were no significant differences $(P<0.05)$ in terms of serum glucose, total protein $(\mathrm{TP})$, glutamic oxaloacetic transaminase (GOT) and glutamic pyruvic transaminase (GPT) among fish fed the experimental diets which is in agreement with Lee et al. (2015a). Overall, in this study, the results of the serum parameters suggested that the dietary additives had no adverse effects on health status of fish (Blaxhall 1972).

Table 5 Serum parameters in juvenile Amur catfish fed the experimental diets for 8 weeks

\begin{tabular}{lccccc}
\hline & \multicolumn{1}{l}{ Diets $^{\mathrm{A}}$} & & & \\
\cline { 2 - 6 } & CONT & SG & YM & BG & SG + BG \\
\hline Glucose (mg/dl) & $67.7 \pm 29.0$ & $65.3 \pm 14.5$ & $61.7 \pm 18.9$ & $54.7 \pm 5.03$ & $53.3 \pm 10.2$ \\
Total protein (g/dl) & $2.8 \pm 0.0$ & $2.9 \pm 0.2$ & $2.7 \pm 0.1$ & $2.9 \pm 0.1$ & $2.9 \pm 0.1$ \\
GOT (U/l) & $153.7 \pm 16.2$ & $95.3 \pm 37.8$ & $109.7 \pm 3.7$ & $140.0 \pm 58.6$ & $94.3 \pm 26.5$ \\
GPT $(\mathrm{U} / \mathrm{l})^{\mathrm{C}}$ & $6.3 \pm 0.5$ & $5.3 \pm 0.5$ & $5.7 \pm 0.5$ & $5.7 \pm 0.6$ & $6.3 \pm 0.5$ \\
\hline
\end{tabular}

Values are mean \pm SD from the triplicate groups of fish where values in each row without superscripts are insignificantly different $(P>0.05)$

${ }^{\mathrm{A}}$ Footnote: Refer to Table 2

${ }^{\mathrm{B}} \mathrm{GOT}=$ Glutamic oxaloacetic transaminase

${ }^{\mathrm{C}} \mathrm{GPT}=$ Glutamic pyruvic transaminase
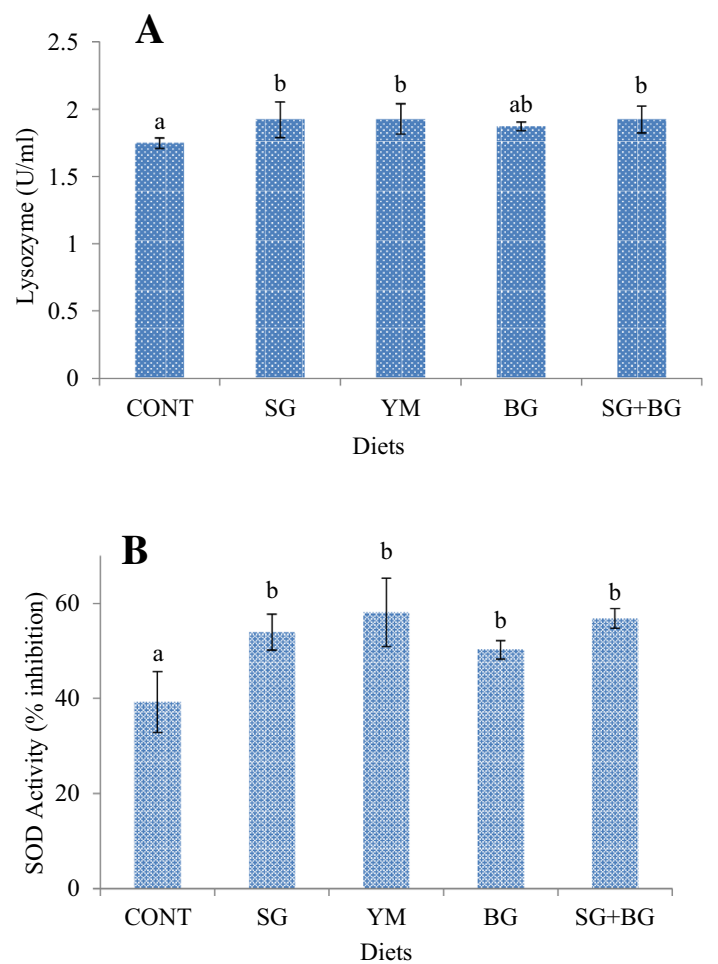

Fig. 1 Lysozyme (a) and superoxide dismutase, SOD (b) activities of juvenile Amur catfish fed the different dietary additives for 8 weeks 
Innate immune responses

Results on the innate immune responses of juvenile Amur catfish fed the experimental diets are presented in Fig. 1 (a, b). Lysozyme activity was significantly higher among fish fed the SG, YM and SG + BG diets than in fish fed the CONT diet $(P<0.05)$. However, there were no significant differences in lysozyme activities between fish fed the BG and CONT diets $(P>0.05)$. Moreover, fish fed the SG, YM, BG and SG + BG diets did not show significant differences in terms of lysozyme activities. Superoxide dismutase (SOD) activity was significantly higher among fish fed the SG, BG, YM and SG + BG diets than in fish fed the CONT diet $(P<0.05)$. However, there were no significant differences in SOD activities among fish fed the SG, YM, BG, and $\mathrm{SG}+\mathrm{BG}$ diets $(P>0.05)$. The results of the innate immune responses may attribute to the increased immunity of fish fed the additive supplemented diets compared to that of control diet. Innate immune response is the fundamental defense mechanism in fish and also plays a key role in the acquired immune response and homeostasis through a system of receptor proteins (Halver and Hardy 2002; Uribe et al. 2011; Reverter et al. 2014; Srivastava and Pandey 2015). Lysozyme is produced mainly by macrophages in response to microbial components and many other immune stimulants (Siwicki and Anderson Siwicki and Anderson 1993; Ring $\varnothing$ et al. 2012) and it is a preferred marker of the immune response due to its close association with leucocytes (Kiron 2012). On the other hand, SOD are metalloenzymes that catalyze the dismutation of the superoxide radical $\left(\mathrm{O}^{2-}\right)$ into hydrogen peroxide $\left(\mathrm{H}_{2} \mathrm{O}_{2}\right)$ and molecular oxygen $\left(\mathrm{O}_{2}\right)$ (Shao et al. 2010), which provides an important defense against oxidative damage. In line with the present study, improved immune responses have been recorded in cultured fish with several feed additives such as the combination of $\beta$-glucan and BAISM (Yoo et al. 2007), $\beta$-glucan (Ai et al. 2007), herbal extracts (Chelladurai et al. 2014), yellow loess (Lee et al. 2015b), Song-gang ${ }^{\circledR}$ stone (Lee et al. 2015b) and Yucca meal (Njagi et al. 2017).

\section{Challenge test}

The cumulative survival rate of juvenile Amur catfish fed the experimental diets after 14 days of intraperitoneal injection with E. tarda is shown in Fig. 2. Mortality was recorded in fish fed the CONT diet from the third day after the injection, which may indicate the first sign of pathogenicity of injected bacteria on visual observation during the challenge test. At the end of 14 days, the cumulative survival rates of fish fed the SG and $\mathrm{SG}+\mathrm{BG}$ diets were significantly higher than those of fish fed the BG and control diets $(P<0.05)$. However, there were no significant differences in cumulative survival rates among fish fed the $\mathrm{SG}, \mathrm{SG}+\mathrm{BG}$ and YM diets $(P>0.05)$. Moreover, fish fed the YM, BG, and CONT diets did not show significant differences in cumulative survival rates at the end of the challenge test. The bacterium, E. tarda is a gramnegative bacterium associated with the freshwater ecosystem. It can colonize in a wide variety of amphibians, reptiles and fish which may ultimately cause diseases in these animals that evidenced in emphysematous putrefactive disease of the catfish (Meyer and Bullock 1973). In this study, results of the challenge test

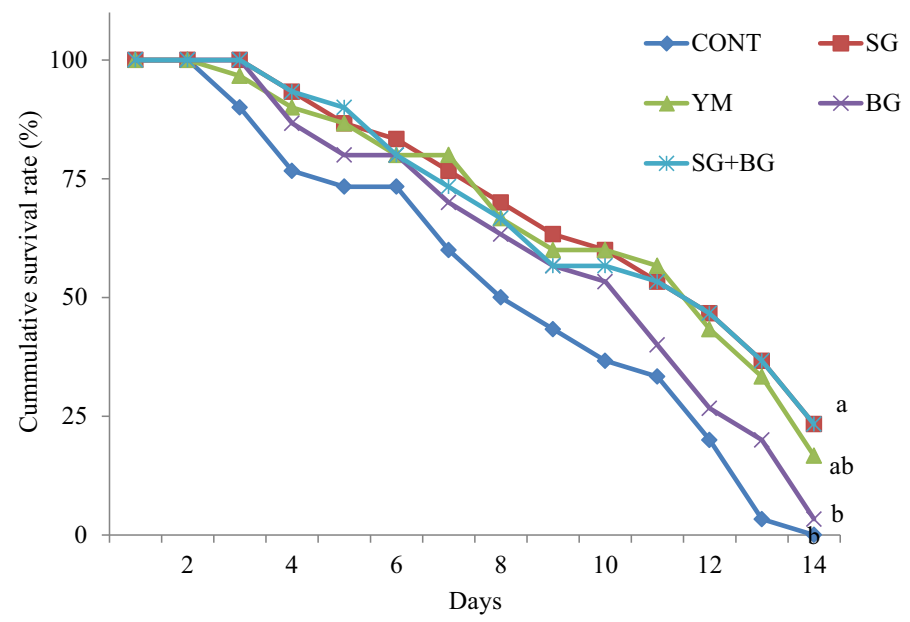

Fig. 2 Cumulative survival of juvenile Amur catfish after intraperitoneal injection with Edwardsiella tarda for 14 days 
corroborated to the results of the WG, SGR, FE and PER in juvenile Amur catfish. These results with SG are similar to those of Lee et al. (2015a) and Won et al. (2017) reported with yellow loess and SG, respectively, in rainbow trout (Oncorhynchus mykiss) and Shakhar et al. (2015) with Macsumsuk ${ }^{\circledR}$ in Nile tilapia (Oreochromis niloticus) which were natural sources of minerals.

\section{Conclusion}

In conclusion, based on the WG, SGR, FE, PER, lysozyme, SOD and resistance against bacteria, dietary Songgang $^{\circledR}$ stone (SG) and a combination of Song-gang ${ }^{\circledR}$ stone and $\beta$-glucan $(\mathrm{SG}+\mathrm{BG})$ could have more positive responses compared to the YM or BG diet alone in terms of improved growth performance, innate immune responses and disease resistance in juvenile Amur catfish. Moreover, as the price contribution for the unit kg of feed of Song-gang ${ }^{\circledR}$ stone is only 0.04 cents $(\phi) \mathrm{kg}^{-1}$ of feed, it could be the more cost-effective feed additive for catfish culture among the additives that we had tested.

Acknowledgements This research work was supported by the Pukyong National University Research Fund in 2016 (C-D-20160237). The authors would like to appreciate the help and cooperation of students and staff of Feeds and Foods Nutrition Research Center (FFNRC) at PKNU during the feeding trial and the analyses of the samples.

Open Access This article is distributed under the terms of the Creative Commons Attribution 4.0 International License (http:// creativecommons.org/licenses/by/4.0/), which permits unrestricted use, distribution, and reproduction in any medium, provided you give appropriate credit to the original author(s) and the source, provide a link to the Creative Commons license, and indicate if changes were made.

\section{References}

Ai Q, Mai K, Zhang L, Tan B, Zhang W, Xu W, Li H (2007) Effects of dietary $\beta-1,3$ glucan on innate immune response of large yellow croaker, Pseudosciaena crocea. Fish Shellfish Immunol 22:394-402

Blaxhall PC (1972) The haematological assessment of the health of freshwater fish. J Fish Biol 4:593-604

Bricknell I, Dalmo RA (2005) The use of immunostimulants in fish larval aquaculture. Fish Shellfish Immunol 19:457-472

Castell JD, Tiews K (1980) Report on the EIFAC, IUNS and ICES working group on the standardization of methodology in fish nutrition research. EIFAC Technical Paper 36. Hamburg, Federal Republic of Germany, 21-23 March

Cheeke PR, Piacente S, Oleszek W (2006) Anti-inflammatory and anti-arthritic effects of Yucca schidigera: a review. J Inflamm $3: 6$

Chelladurai G, Veni T, Mohanraj J, Nagarajan R (2014) Effect of Herbal Extracts Supplemented diets on Non Specific Immunity and Resistance to Aeromonas hydrophila in Indian cat fish (Mystus montanus). J Zool Bios Res 1:10-14

Choi S, Ko S, Park G, Lim S, Yoo G, Lee J, Bai SC (2004) Utilisation of song-gang stone as dietary additive in juvenile olive flounder Paralichthys olivaceus. J Fish Mar Sci Edu 17:39-45

Craig S, Helfrich LA (2009) Understanding Fish Nutrition, Feeds, and Feeding. Virginia Cooperative Extension. Publication no. 420-256

Das BK, Pattnaik P, Debnath C, Swain DK, Pradhan J (2013) Effect of $\beta$-glucan on the immune response of early stage of Anabas testudineus (Bloch) challenged with fungus Saprolegnia parasitica. SpringerPlus 2:197

FAO (2015) FAO Global Aquaculture Production database updated to 2013-summary information

FAO (2016) Fisheries and Aquaculture Information and Statistics Branch http://www.fao.org/figis/servlet/SQServlet?file=/work/ FIGIS/prod/webapps/figis/temp/hqp_7287501540920455907.xml\&outtype=html-15/07/2016

Gaber MM (2006) The effects of plant-protein-based diets supplemented with yucca on growth, digestibility, and chemical composition of Nile Tilapia (Oreochromis niloticus, L) Fingerlings. J World Aqua Soc 37:74-81

Güroy B, Mantoglu S, Kayali S, Sahin I (2014) Effect of dietary Yucca schidigera extract on growth, total ammonia-nitrogen excretion and haematological parameters of juvenile striped catfish Pangasianodon hypophthalmus. Aquac Res 45:647-654

Halver JE, Hardy RW (2002) Fish Nutrition. Academic Press, California, pp 529-531

Harikrishnan R, Balasundaram C, Heo MS (2011) Impact of plant products on innate and adaptive immune system of cultured finfish and shellfish. Aquaculture 317:1-15

Ighwela KA, Ahmad AB, Abol-Munafi AB (2014) The selection of viscerosomatic and hepatosomatic indices for the measurement and analysis of Oreochromis niloticus condition fed with varying dietary maltose levels. Int J Fauna Biol Stud $1: 18-20$

Kaplan EL, Meier P (1958) Nonparametric estimation from incomplete observations. J Am Stat Assoc 53:457-481

Kiron V (2012) Fish immune system and its nutritional modulation for preventive health care. Anim Feed Sci Tech 173:111-133

Lee S, Taddese F, Won S, Yun H, Kim S, Park J, Bai SC (2015a) Natural feed additives enhance rainbow trout performance. Global Aquaculture Alliance, Innovation, Missouri, pp 73-75 
Lee YK, Katya K, Yun H, Yoon MY, Park K, Sung JS, Shin HS, Bai SC (2015b) Evaluation of dietary yellow loess as an antibiotic replacer on growth, immune responses, serological characteristics and disease resistance in rainbow trout Oncorhynchus mykiss. Aquac Nutri. https://doi.org/10.1111/anu.12348

Lee S, Moniruzzaman M, Yun H, Park Y, Mann J, Bai SC (2016) Comparative studies on effects of extruded pellets and dough type diets on growth, body composition, hematology and gut histology of juvenile Japanese Eel, Anguilla japonica (Temminck et Schlegel). J Fish Aqua Sci 11:378-384

Meena DK, Das P, Kumar S, Mandal SC, Prusty AK, Singh SK, Akhtar MS, Behera BK, Kumar K, Pal AK, Mukherjee SC (2013) Beta-glucan: an ideal immunostimulant in aquaculture (a review). Fish Physiol Biochem 39:431-457

Meyer FP, Bullock GL (1973) Edwardsiella tarda, a new pathogen of channel catfish, Ictalurus punctatus. J Appl Microb $25: 155-156$

Njagi GW, Lee S, Won S, Hong JW, Hamidoghli A, Bai SC (2017) Effects of dietary Yucca meal on growth, haematology, nonspecific immune responses and disease resistance of juvenile Nile tilapia, Oreochromis niloticus (Linnaeus, 1758). Aquac Res pp 1-10 (in press) doi:10.1111/are.13264

NRC (2011) Nutrient requirements of fish. National Academy Press, Washington, pp 221-227

Oakenfull D, Sidhu GS (2005) Saponins. In Toxicants of Plant Origin Volume 2. Edited by: Cheeke P.R. Boca Raton, Fla: CRC Press; 1989, pp 97-141

Park Y, Moniruzzaman M, Lee S, Hong J, Won S, Lee JM, Yun H, Kim KW, Ko D, Bai SC (2016) Comparison of the effects of dietary single and multi-probiotics on growth, non-specific immune responses and disease resistance in starry flounder, Platichthys stellatus. Fish Shellfish Immunol 59:351-357

Piacente S, Pizza C, Oleszek W (2005) Saponins and Phenolics of Yucca schidigera Roezl: chemistry and Bioactivity. Phytochem Rev 4:177-190

Reverter M, Bontemps N, Lecchini D, Banaigs B, Sasal P (2014) Use of plant extracts in fish aquaculture as an alternative to chemotherapy: current status and future perspectives. Aquaculture 433:50-61

Ring $\varnothing$ E, Olsen RE, Vecino JLG, Wadsworth S, Song SK (2012) Use of immunostimulants and nucleotides in aquaculture: a review. J Mar Sci Res Dev 1:104-126

Rufchaie R, Hoseinifar SH (2014) Effects of dietary commercial yeast glucan on innate immune response, hematological parameters, intestinal microbiota and growth performance of white fish (Rutilus frisii kutum) fry. Croatian J Fish 72:156-163

Sakai M (1999) Current research status of fish immunostimulants. Aquaculture 172:63-92

Shahkar E, Park G, Lee DM, Kwak S, Bai SC (2015) Effects of dietary Macsumsuk ${ }^{\circledR}$ supplementation on growth performance, haematological parameters, disease resistance and body composition of juvenile Nile tilapia, Oreochromis niloticus L. J Appl Anim Res 43:125-130

Shao XP, Liu WB, Xu WN, Lu KL, Xia W, Jiang YY (2010) Effects dietary copper sources and levels on performance, copper status, plasma antioxidant activities and relative copper bioavailability in Carassius auratus gibelio. Aquaculture 308:60-65

Sirimanapong W, Adams A, Ooi EL, Green DM, Nguyen DK, Browdy CL, Collet B, Thompson KD (2015) The effects of feeding immunostimulant $\beta$-glucan on the immune response of Pangasianodon hypophthalmus. Fish Shellfish Immunol 45:357-366

Siwicki AK, Anderson DP (1993) Non-specific defence mechanisms assay in fish: II. Potential killing activity of neutrophils and macrophages, lysozyme activity in serum and organs. In: Siwicki AK, Anderson DP, Waluga J (eds) Disease diagnosis and prevention methods, FAO-project GCP/INT/526/JPN. IFI, Olsztyn, Poland, pp 105-111

Srivastava PK, Pandey AK (2015) Role of immunostimulants in immune responses of fish and shellfish. Biochem Cell Arch 15:47-73

Uribe C, Folch H, Enriquez R, Moran G (2011) Innate and adaptive immunity in teleost fish: a Review. Vet Medic 56:486-503

Won S, Moniruzzaman M, Lee S, Hong J, Park JK, Kim S, Bai SC (2017) Evaluation of dietary natural mineral materials as an antibiotic replacer on growth performance, non-specific immune responses and disease resistance in rainbow trout, Oncorhynchus mykiss. Aquac Res pp 1-13 (in press) doi:10.1111/are.13295

Yılmaz S, Ergün S, Çelik EŞ (2012) Effects of herbal supplements on growth performance of sea bass (Dicentrarchus labrax): change in body composition and some blood parameters. J BioSci Biotech 1:217-222

Yoo G, Lee S, Kim YC, Okorie OE, Park GJ, Han YO, Choi SM, Kang JC, Sun M, Bai SC (2007) Effects of Dietary $\beta-1,3$ Glucan and feed stimulants in juvenile olive flounder, Paralichthys olivaceus. J World Aquac Soc 38:138-145

\section{Publisher's note}

Springer Nature remains neutral with regard to jurisdictional claims in published maps and institutional affiliations. 